\title{
Missing the starting gun: de alio entry order in new markets, inertia and real option capabilities
}

\author{
Marco S Giarratana \\ Business Department, Universidad Carlos III de Madrid, Madrid, Getafe, Spain
}

Correspondence: Marco S Giarratana, Departamento de Economia de la Empresa, Universidad Carlos III de Madrid, Despacho 6.0.35, Calle Madrid 126, Madrid, Getafe 28903, Spain.

Tel: +34916249613

Fax: +34916249607

E-mail: marco.giarratana@uc3m.es

\begin{abstract}
This article analyses entry order decisions of incumbent firms diversifying from other industries (de alio entrants) in new markets. We study this issue in the Security Software Industry, a high turbulent industry in which de alio firms were first technological movers but start-ups dominate the downstream product market. With a generalized Tobit estimation of observed entry order decisions, we find that pre-entry firm capabilities that should represent strategic options do not significantly explain firm entry order. The article argues that inertial decisions more than rational assessments drive de alio entry order in Security Software.
\end{abstract}

Keywords: entry order; capabilities; real options; inertia; software

\section{Introduction}

$\mathrm{E}$ ntry order decision is one of the most important strategic options (Mitchell, 1991). ${ }^{1}$ When a new market ignites, incumbent firms in other industries (the de alio entrants) face the pivotal decision of whether to enter promptly seizing first mover advantages, or to wait until the market becomes stable (i.e. when a standard consolidates). ${ }^{2}$ A classical example is the case of the radio producers and the emerging television-receiver market during the 1940 s (Klepper and Simons, 2000).

From a researcher point of view, this strategic question is even more interesting when $R \& D$ and innovation dictate the competitive rules in a new market. De novo entrants could imitate knowledge developed by de alio firms and take advantage of their strategic mistakes in the entry order (Christensen, 1997).

In this respect, we would like to highlight two essential regularities. The first is that de alio entrants usually own a diversified technological portfolio and an important strategic advantage due to their experience in other business areas. These firms, that tend to be large and old, produce also by far the largest part of world innovations and patents and they control important downstream cospecialized assets (Pavitt et al., 1989; Hall, 1993).

Second, a wide collection of industry cases shows how de alio entrants prefer to adopt wait-and-see strategies, leaving to de novo firms the task to open new markets (Schnaars, 1994). In addition, empirical evidence (Bhide, 2000) suggests that not only founders of innovative ventures are often former employees of de alio entrants but also they start their businesses exploiting sleeping capabilities of de alio organizations.

Therefore, the creation of new markets and the diffusion of innovations are influenced by two different forces: (i) the ability of latecomers, usually de alio entrants, in surmounting product pioneers; and (ii) the importance of first mover advantages gained by early-entrants, usually de novo firms, that are imitators of the leading technology (Carroll et al., 1996). It is straightforward that the entry order decision of de alio entrants represents the key issue to understand this mechanism.

Current literature leaves significant room to improve our knowledge on entry order decisions of de alio entrants given that the 'where to enter' question is largely more debated than the 'when to enter' question (e.g. Silverman, 1999). Therefore, the aim of this work is to understand whether, aware of this context, de alio entrants take entry order decisions in new markets with a rational perspective. Or whether, conversely, holds the opposite view, that sees the de alio entry order driven by inertial rules that do not take into account all information available (Henderson and 
Clark, 1990). In a rational context, the pre-entry firm capabilities that represent strategic options (Kogut and Kulatilaka, 2001) for the targeted market should influence entry order decisions. On the other hand, inertia would deprive firms of the use of entry order as a strategic tool and, as a corollary, of the optimal exploitation of the firm capability as real options.

We investigate the entry order decisions of de alio entrants with data from Security Software Industry (SSI). SSI represents an ideal test-bed. In SSI, de alio entrants that were first technological movers were late to enter into the final product markets, leaving the opportunity to dominate the industry to the de novo entrants. Focusing on de alio firms, we estimate a generalized Tobit equation that predicts the significant drivers of the entry order decision. In so doing, we select first the sample of de alio entrants in SSI and second, we construct a control sample of potential entrants. We use as core covariates two pre-entry firm capabilities that are often used as strategic options in the literature: patents and alliances. We find that patents and alliances are not statistically significant in explaining entry order of de alio entrants while sector variables and firm profitability are instead significant. This evidence supports the hypothesis that de alio entry order follows an inertial decision rule based on the observation of sector and firm general characteristics, instead of the strategic use of firm capabilities as real options targeted for the new markets.

Our work is embedded in two streams of literature. Many contributions show how de alio entrants are more likely to be followers than first movers into new product area. They interpret this evidence as a rational behaviour of many companies that prefer to adopt a strategy of waiting until the uncertainty of new markets lowers and customer preferences consolidate (Mitchell, 1991). On the other hand, the problems of organizational inertia could be an alternative explanation. De alio entrants show inefficiencies during the phase of recognition, interpretation and use of disperse capability portfolios. Therefore, they are the worst fitted organizational forms to cope with breakthrough innovations and markets (Christensen, 1997). Our paper constitutes therefore an attempt to test simultaneously for the validity of these two traditions using as a test-bed a young industry where the dominant organizational form is the start-up.

Along this view, this article provides one of the few systematic empirical studies that shows the drivers of de alio entry order decision. Several investigations have already studied the effects of entry order on firm performance (Lieberman and Montgomery, 1988), much less is known about firm-specific drivers of entry order. We think that our work contributes to this understudied portion of the literature.

The remainder of the paper is organized as follows. The next section builds the theoretical background while the subsequent section proposes a simple model. Further section shows the empirical results from SSI data and the final section concludes the paper.

\section{Theoretical background}

Literature agrees that de alio entrants in new markets (i.e. entry by incumbents from other sectors) are usually latecomers (Lieberman and Montgomery, 1988; Mitchell, 1991). Some authors have explained this behaviour as the outcome of a rational firm choice, while others as the outcome of organizational inertia.

For example, Mitchell $(1989,1991)$ points out that early entry could convey risks for de alio firms especially if new markets require new co-specialized downstream assets that are difficult to be rapidly built. Moreover, de alio firms usually apply better strategies of imitation and catching-up, once newcomers have tested new products and markets. The costs of imitation and late entry are usually lower than the costs generated by the new market uncertainties (Christensen, 1997). Another important issue is that de alio firms could have low incentives to enter in new market niches because they face problems related to the cannibalization of their existing markets. New goods may reduce sales of existing products (Tushman and Anderson, 1986; Aron and Lazear, 1990; Burgelman, 1994; Klepper, 2001) so that wait-and-see strategies are best fitted. According to Cho et al. (1998), late entry may be the only realistic option for many de alio firms given their competitive posture. De alio firms experience great opportunity costs in investing resources into risky markets, and so they wait until the uncertainty lowers or when new industries and market characteristics become similar to those of existing markets (Smith and Cooper, 1988).

To centre the arguments of the discussion, the analysis on firm pre-entry capabilities is pivotal to understand the entry order decision. Firm capabilities are considered as real options that make firms able to respond to environmental conditions characterized by high level of uncertainty, as in the case of new markets (Kogut and Kulatilaka, 2001). Therefore, in a rational setting, the diverse endowments of firm capabilities that are real options should dictate the pace of firm entry order.

Granted this, a large stream of heterogeneous articles discusses the inertia of de alio firms when they cope with innovations and new markets. Henderson and Clark (1990) highlight two levels of inertia. The first level is a myopic inertia and it refers to the firm inability to recognize the potential links between firm existing capabilities and new business opportunities. Therefore, the main problem in de alio entry decision is not the creation of capabilities that are strategic options in new markets, but in the recognition of these capabilities as strategic options. In the same line, Dosi and Kogut (1993) stress the strategic relevance of the failure to recognize robust matches among firm capabilities, organization structures and market applications. In fact, de alio firms could show inefficiencies during the phase of recognition and interpretation of the environment, a preliminary condition of any strategic actions and responses. In a seminal work, Jelinek (1977: 21) points out that these rigidities are generated by the fact that de alio firms interpret environments with a programmed vision, because 'they only see what they are programmed to perceive'. Similarly, other authors (Barr, 1998; Grever and Taylor, 2000) investigate the links between the cognitive process of manager teams and the timing of strategic changes. They find that in de alio firms the process of interpretation is time consuming. This prevents managers to respond quickly to potential opportunities. Since changes in activities are consistent and follow changes in 
interpretations, they generate adaptive instead of anticipating behaviours. Levinthal and March (1993: 97-99) use the term myopia in assessing problems with change and innovation. As these authors state, 'learning has its own traps', because 'problems that are not seen do not exist'. The application of firm rationality on future markets and customers is a costly process that organizations activate when the profitability of existing markets decreases. This view is similar to Brock and Hommes' (1997): economic agents use new rational tools only when there is high variance in the realized profits, while they prefer to use simple rules of behaviour, that is, consolidated routines à la Nelson and Winter (1982), when prediction errors are small.

The second level of inertia is the procedural inertia. This inertia makes de alio entrants slow in responding to innovative challenges even when they perfectly realize the strategic link between capabilities and new markets. Several scholars (Burgelman, 1994; Dowell and Swaminathan, 2000) illustrate how re-orienting an organization structure is a time consuming operation. In interviews conducted by Dougherthy and Heller (1994), product innovation managers confirm that de alio organizations tend to face problems in adapting rapidly to new environments. Inertia appears when the speed of reorganization is lower than the rate at which external conditions change. Therefore, de alio entrants have slow response times not because they are slow in detecting the link between capabilities and opportunities, but because the process of transforming capabilities in strategic options inside organization structures takes longer (Dougherthy and Hardy, 1996). The presence of pre-existing practices, coordination procedures and specificities prevents de alio firms to make quickly operative the capability platform useful for the new product markets. Firm internal financial markets could generate these inefficiencies. Chesbrough (2000) illustrates several cases in which the internal financial market of de alio entrants fails in providing financial back-up to innovative projects that create new capabilities.

\section{A simple probabilistic representation}

Firm pre-entry capabilities that represent strategic options should affect entry order decisions (Kogut and Kulatilaka, 2001). This means that heterogeneity in the capability distribution in de alio entrants should account for heterogeneity in the entry order decisions. Given the targeted market, some firms will perform better with a wait-and-see strategy because they need to build up the required resources, while firms that already own the required capabilities could instead enter promptly.

Let us assume that for each firm $i$, the total discounted net profits of an entry in a new market is:

$$
\Pi_{i}^{t}=\Pi^{t}\left(v_{i}\right)
$$

where $t$ is $1<t<T$, with $T$ a final long-run time horizon.

$v_{i}$ indicates the firm-specific capabilities tailored to extract profits in the new market. Firms show different values of $v_{i}$, viz they show heterogeneity in owning the 'right' capability platform for the new market. We impose that $v_{i} \sim \Psi$, where $\Psi$ is a continuous random distribution. The firm compares the potential entry profits with a not-entry option. The not-entry profits equals to

$$
\Pi^{0}=\Pi(z)
$$

$\bar{z}_{i}$ is the vector of pre-determined firm assets, that is, exogenous or quasi-exogenous firm characteristics that are not strictly linked with the performance in the new market. Given $\bar{z}_{i}$, each firm is identified by the vector $\left(v_{i}\right)$ that characterizes the strategic firm posture in the decision of entry.

Kogut and Kulatilaka (2001) and Winter (1987) highlight that firms are characterized by several capabilities that could be applied only in the existing firm businesses or that could be used to compete in new end-markets. These capabilities represent ex ante strategic options. For example, consider the case of a US radio producer that enters in the emerging US television-receiver market during the 1940s (Klepper and Simons, 2000). The radio producer could own particular technological expertises (e.g. a patented shadow mask tube technology) or have recently acquired some local key distributor for the televisionreceiver market. By contrast, if this potential entrant is from Maryland or from California, or if the founder has or not a Ph.D. in Communication engineering are clearly variables that control for some pre-determined and quasiexogenous firm characteristics. In the followings, we will indicate with $v_{i}$ the strategic option variables and $\bar{z}_{i}$ the pre-determined quasi-exogenous assets.

Assuming a perfect foresight, firms choose whether to enter in the new market, and then, if they enter, the optimal entry order. So, a firm $i$ will decide to enter in the new market if exists at least one $t^{\circ} \in[1, T]$ that satisfies $\Pi^{t}\left(v_{i}\right)>\Pi^{0}\left(\bar{z}_{i}\right)$. If $\Pi_{i}^{t}\left(v_{i}\right) \leqslant \Pi^{0}\left(\bar{z}_{i}\right) \forall t \in[1, T]$ the firm will not enter. Given the entry, then a rational firm will decide the optimal $t^{*}$ that maximizes $\Pi^{t}\left(v_{i}\right)$ and the observed entry order equals to $t^{*} \mid \Pi^{t *}\left(v_{i}\right)>\Pi^{t}\left(v_{i}\right) \forall t \in[1, T]$.

So, the optimal entry order decision will be:

$$
\left\{\begin{array}{ll}
t_{i}=t^{*} & \text { if } \prod^{t^{*}}\left(v_{i}\right) \geqslant \prod^{0}\left(z_{i}\right) \\
t_{i}=0 & \text { if } \prod^{t^{*}}\left(v_{i}\right) \leqslant \prod^{0}\left(z_{i}\right)
\end{array} \quad \forall t \in[1, T]\right.
$$

From equation (3), the following equation (4) solves the entry decision (yes/no) for the firm $i$. As one could observe, the entry decision is mainly a function of the $\bar{z}_{i}$ variables:

$$
\operatorname{Prob}\left\{v_{i} \geqslant \prod^{t^{*}}\left[\prod^{y}(z)\right]\right\}=1-\Psi\left\{\prod^{t^{*}}\left[\prod^{0}\left(z_{i}\right)\right]\right\}
$$

Given the entry, the observed optimal entry order $t^{*}$ should be mainly influenced by $v_{i}$, with $t^{*}=h\left(v_{i}\right)$. Generalizing these considerations, given a dichotomous variable $Y=0,1$ that explains the entry decision, and a discrete variable $J=t^{*}$ representing the optimal entry order, given the entry, we could expect that

$$
\left\{\begin{array}{l}
Y=g(z)+\varepsilon_{i} \\
J_{i}=h\left(v_{i}\right)+\eta_{i}
\end{array}\right.
$$

Let us now introduce the two types of inertia. The myopic inertia implies that firms do not observe $v_{i}$ because they have difficulties in recognizing potential applications of their actual capabilities in the new markets. Under this 
myopic assumption, we could reasonably suppose that firms could only observe the capabilities of the average firm entered in the new market, defined as $\mu$. So, firms will take the decision of entry according to a simple rule: $\Pi^{t}(\mu)>\Pi^{0}\left(\bar{z}_{i}\right)$. The entry decision and the time of entry are now influenced by $\bar{z}_{i}$ and by the current capability platform of firm entered in the new market, $\mu$. Put it simply, a firm looks at the average characteristics of the entered firms, compares them to its profitability and capabilities and it decides the entry.

Let us turn now the attention to the possible effects of a procedural inertia. Under this assumption, firms could estimate correctly their optimal $t^{*}$, given $v_{i}$, but they cannot make the decision operative. In other words, the observed time of entry of each firm is $t^{\text {observed }}=t^{*}+P_{i}$, where $P_{i}$ is the lag-time due to procedural inertia. In other words, the process of creating the capability base necessary to enter at $t^{*}$ is time consuming.

According to Dougherthy and Hardy (1996), firms affected by this type of inertia could not reasonably predict $P_{i}$. Moreover, $P_{i}$ is usually a function of some exogenous variables like size, level of organization rigidity, information flow structure that will enter in our definition of $\bar{z}_{i}$. The higher is $P_{i}$, the more the observed entry order will be influenced again by $\bar{z}_{i}$.

With the introduction of inertia, the principal finding is that inertial firm decisions are driven mainly by exogenous variables $\bar{z}_{i}$ not by the firm capabilities that represent strategic options. On the other hand, full rational firm decisions of entry- $v s$-not entry depend mainly from $\bar{z}_{i}$ variables while decisions of entry order, given the entry, is driven by those firm capabilities that are strategic options to compete into the targeted market, $v_{i}$. In this respect, perfect rational firm decision is a twofold process that accounts for the entry decision and the entry order decision. While in the inertial framework, firms blend the twofold decision in a unique assessment. These findings are quite intuitive: If entry order is a strategic tool, the decision of entry (yes/no) should account for different variables than the entry order decision (e.g. Lieberman and Montgomery, 1988). Concisely, the entry decision is a two-step process that accounts for the effective profitability of entering in new markets, and for the ways this profitability could be strategically improved through the correct decisions on entry order. If firms do not use entry order to compete, their decision tree collapses in a unique choice.

\section{The SSI}

SSI history begins during the mid-1970s, when the market opportunities arising from the military sector spurred established electronic firms to accumulate knowledge in SSI. Table 1 shows the most important firms for patents granted and cited in US Patent Office and Trademark Office's (USPTO) 380 class 'Cryptology' between 1976 and 1992. Large ICT firms and university departments were the first technological movers.

Patented algorithms, especially in the USPTO class 380 'Cryptology', are fundamental to compete in SSI. A crypto algorithm is a procedure that takes the plain text data and transforms it into cipher text. This process could be reversed with a secret key (the usual password). The core of
Table 1 Most cited firms in 380 (Cryptology) USPTO Patent Class, sample patents 19761992

\begin{tabular}{lccc}
\hline Firm & Citations $(C)$ & Patents $(P)$ & $C / P$ \\
\hline IBM & 528 & 46 & 11.47 \\
Motorola & 226 & 24 & 9.41 \\
Scientific Atlanta & 202 & 18 & 11.22 \\
Pitney Bowes & 165 & 16 & 10.31 \\
Qualcomm & 97 & 3 & 32.33 \\
AT\&T & 97 & 8 & 12.12 \\
Pioneer & 95 & 9 & 10.55 \\
Philips & 95 & 7 & 13.57 \\
Aisin Seiki & 83 & 6 & 13.83 \\
Stanford University & 80 & 2 & 40 \\
M.I.T. & 75 & 2 & 37.5 \\
NEC & 72 & 6 & 12 \\
General Instruments & 68 & 8 & 8.5 \\
NCR & 63 & 5 & 12.6 \\
Hitachi & 62 & 4 & 15.5 \\
VISA & 53 & 2 & 26.5 \\
Total & 2061 & 166 & 17.34 \\
Other & 2520 & 224 & 11.81 \\
\hline
\end{tabular}

Data source is the USPTO. First column lists the firms ranked by number of citations received. Second column the number of backward citations, third column the number of patents. The last column shows the ratio between citations and patents. This table shows which are the most important firms cited in the Cryptology technology. As one can see, large ITC firms are the most important sources of patent knowledge spillovers.

security products is the mathematical procedure that lies behind the encryption of data. Patents offer therefore a good protection mechanism against imitation and preservation of intellectual proprietary rights.

From the second half of the 1980s, the industry landscape has dramatically changed. The development of the PC market and Internet gave rise to a demand for civilian purposes, introducing new market needs and products. Estimates from the International Data Corporation ${ }^{3}$ evaluated the world market of SSI at 2.17 billion dollars in 1997 and 3.2 billion dollars in 1998, with an estimate of 4.4 billion dollars for 1999 . With a wide product line, SSI could be now defined as an industry specialized in the design, development and support of security software solutions, namely products that protect data and software on computers and networks.

The increased civilian demand has spurred a flow of firm entry since 1989, the year when the first product was released in the market, making SSI one of the 'hot' sectors of the 1990s (The Economist, 2002). SSI firm entry is basically a de novo entry phenomenon. Hoover's data show that by 1998 the top 15 market leaders in SSI were all start-ups, accounting for about $43 \%$ of the total world market. These top 15 start-ups were granted 88 patents in 380 USPTO class by 1999, with 446 backward citations. Looking at the most important firms cited by these 88 patents, large ICT firms still remain in the leading positions. This highlights a technological dependence of start-up technology upon the knowledge created by large firms (see Table 2).

De alio ICT firms that were the first technological movers and the largest producers of patented inventions, entered 
into SSI with their own products in the last years of the 1990s, on average 10 years after the first successful products of de novo entrants. The evidence presented strongly suggests that, in SSI de alio entrants, even if they were first mover innovators, choose to enter only when the new market was consolidated.

\section{Empirical evidence}

\section{The sample}

Product introduction data give firm entry information. We resort on Infotrac's Promt database that, from a large set of trade journals, magazines and other specialized press, reports several categories of 'events' classified by industrial sectors. This database is the new version of the Predicast database that has been used extensively in the literature. We search for all press articles that report a 'Product announcement', a 'New software release' and a 'Software evaluation' in SSI (SIC Code 73726). Very simply, in this paper firm entry is when the first firm product is announced.

Table 2 Most cited firms by patents granted to the 15 Security Software product market leaders in 1998 (stock of patents at 1999)

\begin{tabular}{lc}
\hline Firm cited & Numbers of citations \\
\hline IBM & 43 \\
Motorola & 27 \\
Compaq-HP & 23 \\
Science Applications & 19 \\
AT\&T & 18 \\
Sun Microsystems & 14 \\
Matsushita & 13 \\
Secure Computing & 13 \\
NSA Labs & 11 \\
Interdigital & 9 \\
Total & 190 \\
Other & 256 \\
\hline
\end{tabular}

Data source is the USPTO. We take the top 15 market leaders in SSI in 1998 according to Hoover's. We collect all the patents granted in the sample period to these market leaders. We analyse the backward citations of these patents and we see which are the firms most cited by these market leaders. Even controlling for the firms that dominate the downstream market for products in SSI, the evidence of Table 1 is confirmed: large ITC firms are the most important sources of patent knowledge spillovers.
From 1989 to 2003, among the 471 firms that entered in the market for encryption products, $6.15 \%$ were de alio entrants (entry by diversification), while $93.85 \%$ were de novo (entry by new firm formation). In this paper, we focus only on de alio order of entry. As a matter of fact, the basic evidence is that only 29 de alio firms enter SSI in about 15 years of industry history. The total number of products released in the market since 1989 is 1269; de alio firms account for $16.39 \%$ of these software packages.

For our econometric purposes, we need a control sample of potential de alio entrants in SSI that do not enter the market. Our conservative approach is to select the sample not randomly, but to use some ad hoc criteria of sampling. To put our hypotheses under a more severe test, we aim indeed to select only the incumbents that could have had the highest probability to enter in SSI. In so doing, we identify as potential entrants firms that were granted at least a patent in 380 class or firms that signed at least a marketing alliance in SSI during our sample period and that are not product releasers. In fact, patents and alliance signal that firms own at least some technology and downstream assets required to enter in SSI. With these criteria, we build a control sample of 145 established firms, which could be defined as potential entrants in SSI. The total firm sample is composed by 174 firms $(145+29)$. Table 3 shows some preliminary statistics of potential entrants by sector.

Figure 1 shows the distribution of de alio entry order; the median value equals 8 , meaning that $50 \%$ of all the incumbents enter after a lag of 8 years from product pioneers. Therefore, the reaction response of incumbents is characterized by some sort of wait-and-see attribute.

Econometric model and dependent variables

We estimate a generalized Tobit equation (Amemiya, 1987), that is a simultaneous equation model. This model accounts for a dichotomous decision regression (1/0) and a time regression equation. The generalized Tobit can be written as:

$$
\left\{\begin{array}{c}
Y=\beta_{v} v+\beta_{z} z+\varepsilon \\
J=\delta_{v} v+\delta_{z} z+\rho
\end{array}\right.
$$

where $Y=0,1$ is the dependent variable capturing the entry decision, $J=1,2,3 \ldots$ is the dependent variable capturing the entry time decision, given the entry. The generalized Tobit allows indeed testing simultaneously the two types of decisions and the corresponding different magnitude and

Table 3 Firm sample by sector

\begin{tabular}{lccccc}
\hline Sector & Firms & Commercial alliances & Patents after 1992 & Patents before 1992 & Sales ('000\$) \\
\hline Electronics & 46 & 1.61 & 17.25 & 1.42 & 16,612 \\
Hardware & 29 & 2.30 & 29.05 & 4.70 & 9,137 \\
Software & 32 & 1.78 & 9.54 & 0.09 & 2,084 \\
Telecommunications & 29 & 1.81 & 25.08 & 2.21 & 13,274 \\
Other & 38 & 1.81 & 8.29 & 0.19 & 71,177 \\
Total & 174 & & & &
\end{tabular}

Data from Infotrac, USPTO, Hoover's. Core sector corresponds to the SIC code of the main business of the firm, Electronics (38), Hardware (357), Software (737), Telecommunication (366). This table shows the basic statistics of the sample according to sector classification. Our sample represents a quite heterogeneous group of de alio entrants from different business experiences. 


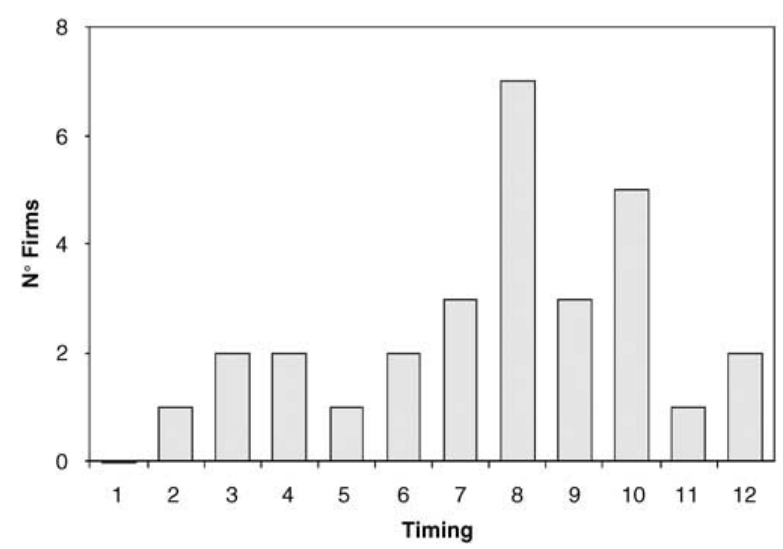

Figure 1 Entry order distribution of de alio entrants in Security Software. Yaxis number of firms entered, $X$ axis year lags from 1989, year of industry inception. The graph shows the dynamics of de alio firm entry in SSI since the industry inception. The most populated cohorts are the 1996 (8-year lags) and the 1998 (10-year lags)

significance of coefficients in the two equations. According toequation (5), we will divide our covariates in capabilitiesbased variables $(v)$ and control variables $(z)$.

According to model intuitions, under inertial assumption we expect that only the $z$ variables should be significant in explaining both the entry and the entry timing decision. In the rational case, the $z$ variables will mainly explain the decision of entry, while the capability variables $(v)$ will determine the entry order. So in econometric terms:

$$
\left\{\begin{array}{l}
\beta_{v}=0 \\
\delta_{v}=0 \\
\delta_{z}, \beta_{z} \neq 0
\end{array}\right.
$$

if the inertial assumption is confirmed, while

$$
\left\{\begin{array}{l}
\beta_{v}=\delta_{z}=0 \\
\delta_{v}, \beta_{z} \neq 0
\end{array}\right.
$$

if the rational hypothesis holds.

\section{Main covariates and controls}

We divide the covariates in the two different groups; one is composed by variables $\left(v_{i}\right)$ that could be defined as strategic options tailored specifically to compete in SSI. The other is formed by controls $(\bar{z})$, namely variables that, not directly linked with the SSI market, are quasi-exogenous, not modifiable in the short run.

Let us illustrate first the capability variables. A previous work on SSI (Fosfuri and Giarratana, 2007) shows that patents and alliances are important factors beyond firm survival in SSI. More general, the real option literature stresses the importance of technological (Dong-Jae and Kogut, 1996) and networking capabilities (Kogut and Kulatilaka, 1994) as strategic options that favour the entry in new markets by incumbent firms. We then introduce the pre-entry number of firm patents in 380 USPTO class (Cryptology). We use three specifications: PATENT1 the patent rough number; PATENT2 the number of patents divided by the logarithm of firm sales; PATENT3 the number of patent multiply by their received citations as a measure of patent value. In an entry time regression model, Schoenecker and Cooper (1998) proxy firm R\&D intensity with $R \& D$ expenditures. In this paper, patents represent a more accurate measure given that we can select with high precision the technological class that is strategic for the industry. Patent and citations data are downloaded from the USPTO website. Cryptology patents are one of the best proxies for firm capabilities that are strategic options in SSI, because the more a firm knows about a key technology for a market, the quicker it should size the business opportunity.

ALLIANCE is the pre-entry number of firm commercial alliances in SSI. It is a common strategy to use collaborative links as a mean to build a dedicated sales force and test market effective profitability (Mitchell and Singh, 1996; Hagedoorn and Duysters, 2002). The fact that a firm signs a number of commercial alliances in a sector before entry with its own products may also signal the high level of market uncertainty perceived. If the number of pre-entry alliances measures the firm's demand for information, the more the information needed, the riskier is the firm

\begin{tabular}{|c|c|c|c|c|}
\hline & Mean & Std Dev & Minimum & Maximum \\
\hline PATENT1 & 13.046 & 29.391 & 0 & 243 \\
\hline PATENT2 & 2.546 & 14.420 & 0 & 187.674 \\
\hline PATENT3 & 2567.247 & 15640.666 & 0 & 144981 \\
\hline ALLIANCE1 & 1.040 & 1.567 & 0 & 29 \\
\hline ALLIANCE2 & 0.167 & 0.266 & 0 & 1.76107 \\
\hline ROA & 0.390 & 0.182 & 0.300 & 0.482 \\
\hline SALES & 7.568 & 2.790 & 0.027 & 11.251 \\
\hline Dummy hardware & 0.167 & 0.374 & 0 & 1 \\
\hline Dummy software & 0.184 & 0.389 & 0 & 1 \\
\hline Dummy electronics & 0.264 & 0.442 & 0 & 1 \\
\hline Dummy telecom. & 0.167 & 0.374 & 0 & 1 \\
\hline
\end{tabular}

Table 4 Covariate descriptive statistics (174 observations)

Data sources are Infotrac, USPTO, Hoover's. The table shows the basic descriptive statistics of the main core variables and controls used in the regression (Table 5). Especially looking at the column of the standard deviation, one can observe an important heterogeneity in the variable values among the sample firms. This means that de alio entrants in SSI are endowed with different real option capabilities. 
Table 5 Results of generalized Tobit estimation

\begin{tabular}{|c|c|c|c|c|c|c|}
\hline \multicolumn{7}{|c|}{ Entry decision $Y=0,1$} \\
\hline Constant & $\begin{array}{c}-3.806^{\star *} \\
(0.366)\end{array}$ & $\begin{array}{c}-3.128^{\star *} \\
(0.619)\end{array}$ & $\begin{array}{c}-3.819^{* *} \\
(0.791)\end{array}$ & $\begin{array}{c}-4.307^{\star \star} \\
(1.450)\end{array}$ & $\begin{array}{c}-4.333^{\star *} \\
(0.658)\end{array}$ & $\begin{array}{c}-4.657^{\star *} \\
(1.982)\end{array}$ \\
\hline PATENT1 & & & -0.003 & -0.004 & & \\
\hline PATENT2 & 0.000 & 0.000 & $(0.007)$ & $(0.008)$ & 0.002 & 0.000 \\
\hline PATENT3 & $(0.002)$ & $(0.002)$ & & & $(0.004)$ & $(0.002)$ \\
\hline ALLIANCE1 & 0.539 & 0.206 & 0.296 & 0.336 & 0.222 & 0.474 \\
\hline ALLIANCE2 & $(0.988)$ & $(0.793)$ & $(0.636)$ & $(0.712)$ & $(0.530)$ & $(0.577)$ \\
\hline ROA & $\begin{array}{c}-0.221^{\star *} \\
(0.031)\end{array}$ & $\begin{array}{c}-0.182^{\star *} \\
(0.077)\end{array}$ & $\begin{array}{c}-0.163^{\star *} \\
(0.037)\end{array}$ & $\begin{array}{c}-0.202^{\star *} \\
(0.044)\end{array}$ & $\begin{array}{c}-0.300^{* *} \\
(0.027)\end{array}$ & $\begin{array}{c}-0.278^{\star *} \\
(0.019)\end{array}$ \\
\hline SIZE & $\begin{array}{l}0.082^{\star *} \\
(0.044)\end{array}$ & $\begin{array}{l}0.079^{* *} \\
(0.049)\end{array}$ & $\begin{array}{c}0.080^{\star} \\
(0.050)\end{array}$ & $\begin{array}{l}0.148^{\star *} \\
(0.062)\end{array}$ & $\begin{array}{c}0.159^{* *} \\
(0.065)\end{array}$ & $\begin{array}{c}0.163^{* *} \\
(0.058)\end{array}$ \\
\hline Dummy hardware & $\begin{array}{l}2.328^{\star *} \\
(0.425)\end{array}$ & $\begin{array}{l}2.229^{\star *} \\
(0.511)\end{array}$ & $\begin{array}{l}2.083^{\star *} \\
(0.680)\end{array}$ & $\begin{array}{l}2.521^{\star *} \\
(0.524)\end{array}$ & $\begin{array}{l}2.287^{\star *} \\
(0.194)\end{array}$ & $\begin{array}{l}2.115^{\star *} \\
(0.786)\end{array}$ \\
\hline Dummy software & $\begin{array}{l}2.428^{* *} \\
(0.370)\end{array}$ & $\begin{array}{l}2.940^{* *} \\
(0.948)\end{array}$ & $\begin{array}{l}2.925^{\star *} \\
(0.374)\end{array}$ & $\begin{array}{l}2.293^{* *} \\
(0.850)\end{array}$ & $\begin{array}{l}2.478^{\star *} \\
(0.232)\end{array}$ & $\begin{array}{l}2.270^{\star *} \\
(0.809)\end{array}$ \\
\hline Dummy electronics & $\begin{array}{c}0.819 \\
(0.555)\end{array}$ & $\begin{array}{c}0.760 \\
(0.673)\end{array}$ & $\begin{array}{c}0.604 \\
(0.596)\end{array}$ & $\begin{array}{c}1.240^{\star} \\
(0.596)\end{array}$ & $\begin{array}{c}1.701^{\star} \\
(0.803)\end{array}$ & $\begin{array}{c}1.596^{\star} \\
(0.624)\end{array}$ \\
\hline Dummy telecom. & $\begin{array}{c}1.357^{\star} \\
(0.571)\end{array}$ & $\begin{array}{c}1.254^{\star} \\
(0.523)\end{array}$ & $\begin{array}{c}1.582^{\star} \\
(0.595)\end{array}$ & $\begin{array}{l}1.903^{\star *} \\
(0.694)\end{array}$ & $\begin{array}{c}1.270 \\
(0.701)\end{array}$ & $\begin{array}{c}1.296^{\star} \\
(0.657)\end{array}$ \\
\hline
\end{tabular}

Entry order decision $J=1,2,3, \ldots$

\begin{tabular}{|c|c|c|c|c|c|c|}
\hline Constant & $\begin{array}{l}13.748^{* *} \\
(2.198)\end{array}$ & $\begin{array}{l}13.687^{* *} \\
(2.208)\end{array}$ & $\begin{array}{l}13.269^{\star *} \\
(2.798)\end{array}$ & $\begin{array}{l}15.042^{* *} \\
(3.643)\end{array}$ & $\begin{array}{l}15.548^{* *} \\
(4.624)\end{array}$ & $\begin{array}{l}15.216^{* *} \\
(3.456)\end{array}$ \\
\hline PATENT1 & & & 0.002 & -0.013 & & \\
\hline PATENT2 & 0.000 & 0.000 & $(0.009)$ & $(0.044)$ & 0.002 & 0.000 \\
\hline PATENT3 & $(0.002)$ & $(0.004)$ & & & $(0.005)$ & $(0.001)$ \\
\hline ALLIANCE1 & -0.818 & -0.702 & -0.811 & -1.328 & -1.152 & -1.237 \\
\hline ALLIANCE2 & $(0.539)$ & $(0.519)$ & $(0.647)$ & $(1.218)$ & $(1.549)$ & $(1.717)$ \\
\hline ROA & $\begin{array}{c}-0.613^{* *} \\
(0.071)\end{array}$ & $\begin{array}{c}-0.667^{\star *} \\
(0.075)\end{array}$ & $\begin{array}{c}-0.675^{\star *} \\
(0.065)\end{array}$ & $\begin{array}{c}-0.082^{\star *} \\
(0.006)\end{array}$ & $\begin{array}{c}-0.084^{\star *} \\
(0.004)\end{array}$ & $\begin{array}{c}-0.070^{*} \\
(0.001)\end{array}$ \\
\hline SIZE & $\begin{array}{c}0.016 \\
(0.215)\end{array}$ & $\begin{array}{c}0.028 \\
(0.353)\end{array}$ & $\begin{array}{c}0.024 \\
(0.189)\end{array}$ & $\begin{array}{c}-0.046 \\
(0.168)\end{array}$ & $\begin{array}{c}-0.081 \\
(0.689)\end{array}$ & $\begin{array}{c}-0.062 \\
(0.953)\end{array}$ \\
\hline Dummy hardware & $\begin{array}{c}-4.665^{\star *} \\
(1.813)\end{array}$ & $\begin{array}{c}-4.166^{* *} \\
(1.313)\end{array}$ & $\begin{array}{c}-4.378^{\star *} \\
(1.509)\end{array}$ & $\begin{array}{c}-4.557^{\star *} \\
(1.778)\end{array}$ & $\begin{array}{c}-5.668^{* *} \\
(1.676)\end{array}$ & $\begin{array}{c}-5.232^{* *} \\
(1.172)\end{array}$ \\
\hline Dummy software & $\begin{array}{c}-3.915^{\star *} \\
(1.054)\end{array}$ & $\begin{array}{c}-3.684^{* *} \\
(1.085)\end{array}$ & $\begin{array}{c}-3.928^{\star *} \\
(1.037)\end{array}$ & $\begin{array}{c}-3.109^{* *} \\
(1.067)\end{array}$ & $\begin{array}{c}-3.305^{\star *} \\
(1.015)\end{array}$ & $\begin{array}{c}-3.247^{\star *} \\
(1.058)\end{array}$ \\
\hline Dummy electronics & $\begin{array}{r}-5.202^{\star} \\
(2.609)\end{array}$ & $\begin{array}{c}-5.940^{\star *} \\
(2.716)\end{array}$ & $\begin{array}{r}-5.236^{\star} \\
(2.734)\end{array}$ & $\begin{array}{c}-5.839^{\star *} \\
(2.848)\end{array}$ & $\begin{array}{c}-5.352^{\star *} \\
(2.366)\end{array}$ & $\begin{array}{c}-5.122^{\star *} \\
(2.454)\end{array}$ \\
\hline Dummy telecom. & $\begin{array}{c}-5.590^{\star *} \\
(1.562)\end{array}$ & $\begin{array}{c}-5.696^{* *} \\
(1.559)\end{array}$ & $\begin{array}{c}-5.434^{\star *} \\
(1.495)\end{array}$ & $\begin{array}{c}-5.873 \\
(3.635)\end{array}$ & $\begin{array}{c}-5.618 \\
(3.291)\end{array}$ & $\begin{array}{c}-5.396 \\
(3.966)\end{array}$ \\
\hline Log-likelihood & -104.7 & -103.8 & -105.5 & -112.7 & -135.4 & -125.1 \\
\hline
\end{tabular}

174 Observations. Dependent variable in the first step entry decision (yes/no), in the second step entry order $(1,2,3 \ldots$ year lags from 1989). Standard errors in parentheses. Level of significance ${ }^{* *} 0.05,{ }^{*} 0.10$. The core variables of this study, patents and alliances, are not significant in explaining entry order decisions of de alio entrants. Therefore, the real option capabilities of the de alio firms do not explain with statistical significance the entry order patterns of de alio firms.

perception of a market. We adopt the same sector precision used along the paper, selecting only the agreements classified with the SIC code 73726. Information about alliances is similarly drawn from Infotrac's Insite Promt database. We download two categories of firm events: strategic alliances and joint-ventures, both with an evident marketing, commercial and distribution aim. With these types of alliances, the de alio firm is mainly acting as a market distributor, reselling or including SSI products of other firms in its software packages. We use two specifications: ALLIANCE1 the number of alliances and ALLIANCE2 the number of alliances divided by the logarithm of firm 
sales. In sum, ALLIANCE is another good proxy for firm capability options, since the riskier the firm perceived the market, the more useful will be networking as a strategic option (Kogut and Kulatilaka, 1994).

We now move to control variables, $\bar{z}$ of our model. SALES are the firm sales at the year of entry. It is the classical proxy for size. We use it in the log specification. Sales data are taken from Hoover's (www.hoovers.com), an online database, which collects financial data for the Security Software \& Services industry. Moreover, size could be interpreted as a rough proxy of firm level of diversification. Therefore, it could also test the ability of more diversified firm to promptly absorb external knowledge, recognize new business opportunity and exploiting economies of scope (Henderson and Cockburn, 1996). Finally, size is highly correlated with age, and it could measure firm experience.

ROA is the ratio between the firm Return on Asset and the average ROA of all the firms already competing in SSI at the firm entry year. Note that the standardization is also needed to avoid problems of collinearity. It measures the proportion between the profitability of the new market and the one derived from activities in existing businesses. This covariate aims to test the Aron and Lazear' (1990) assumption that firm tend to seek risky new markets when profits in existing businesses are decreasing. Data are from Hoover's.

SECTOR DUMMIES. Sector dummies aim to capture the technological and downstream distance between incumbent core sectors and SSI. In fact, it should be easier to enter in SSI being a software firm rather than a telecommunication or a consumer electronic producer (Teece et al., 1994). We introduce four dummy variables: software (Dummy Software), hardware (Dummy Hardware), consumer electronics (Dummy Electronics) and telecommunications (Dummy Telecommunications). Firm core business was taken from Hoover's. The omitted OTHER dummy accounts mainly for consultancy firms and credit card producers.

For those firms that did not enter in the sample period we assume that they will never enter (data are right censored).

Table 4 provides the basic statistics for the covariates.
Results

We estimate a generalized Tobit model using the above covariates. Looking at the results (see Table 5), firm strategic capabilities, PATENT and ALLIANCE, in all their specifications, are not significant. The results replicate the case of equation (7) and the inertial behaviour seems to be confirmed by SSI data.

About the controls, ROA is significant both in the entry and entry time decision. The sign is in line with prediction: the lower is the level of the profitability in the existing business, the higher is the firm probability to enter in new business. In the entry time regression the sign is negative. The interpretation is that, given the entry, most of the firms wait until the observed profits in the new market were high enough.

SALES has a significant and positive effect on the entry probability while do not affect the time of entry. This effect is expected: Largest firms could count on more resources to build up entry attempts and they have more experience in building business model for a new entry.

Sector dummies are very important in the entry decision process. All dummies tend to be significant. Data confirm an important regularity: It was easier to enter in SSI for software or hardware producers compared to all the other sectors. Sector proximities make a difference. Although intuitive, this finding is remarkable, because it is quite uncommon to find this hypothesis tested in literature.

Trying to draw some general insights from these results, the entry decision is influenced mainly by the proximity between the new market and the firm core business, by the level of expected average profitability of the new market and by firm size, while firm ad hoc patent and networking capabilities does not play any role. SSI data seem to support the assumption that de alio entrants utilize adapting mechanisms of decision that do not take in account entry order as a strategic tool. Firm capabilities that could be strategic options do not affect the process of entry while controls tend to explain most of the firm entry variance. Roughly speaking, in SSI incumbent entry time decisions are similar to a process of repetitive 'rule of the thumb'

Table 6 Descriptive statistics of core covariates in the most populated entry order cohorts

\begin{tabular}{|c|c|c|c|c|c|}
\hline Entry order time (year lags from 1989) & 12 & 10 & 9 & 8 & 7 \\
\hline & \multicolumn{5}{|c|}{ Alliances } \\
\hline Average & 3.5 & 2.8 & 22.6 & 4.42 & 3.33 \\
\hline Stand. Dev. & 2.12 & 2.38 & 7.76 & 3.69 & 3.21 \\
\hline $\operatorname{Max}$ & 5 & 7 & 29 & 10 & 7 \\
\hline \multirow[t]{2}{*}{ Min } & 2 & 1 & 14 & 1 & 1 \\
\hline & \multicolumn{5}{|c|}{ Patents } \\
\hline Average & 42 & 11.8 & 32 & 34.1 & 20.6 \\
\hline Stand. Dev. & 16.97 & 7.46 & 22.11 & 72.8 & 35.7 \\
\hline Max & 54 & 19 & 57 & 198 & 62 \\
\hline Min & 30 & 2 & 15 & 0 & 0 \\
\hline
\end{tabular}

Data sources are Infotrac and USPTO. We calculate average values for alliances and patents in the time cohorts that show the highest firm entry rates. Entry cohorts are indicated by year lags from industry inception (1989). Each entry cohort is populated by firms that show a heterogeneous endowment of patents and alliances. This is consistent with the regression findings (Table 5): heterogeneous firms in terms of real option capabilities took similar decisions of entry order. 
interpretation of the competitive landscape. Firm entry order time appears to be not the direct outcome of a process of rational strategic decision, but a sub-product of an entry- $v s$-no entry algorithm that firms activate.

In order to confirm this view, we calculated the Pearson correlation coefficient among residuals of the two estimations, $\hat{\varepsilon}$ and $\hat{\rho}$. Not surprising, the correlation coefficient equals 0.405 with a significance level of 0.028 .

Moreover, Table 6 shows some descriptive statistics for the most populated entry time cohorts. It is evident the high heterogeneity in terms of capabilities among firms inside the cohorts. Why firms that have so different capability platforms take the same entry time decision? Our answer is that entry order decisions of heterogeneous firms could coincide, if the firm capabilities that are strategic options are negligible elements in firm decision processes. If we think that de alio entrants are to some extent inertial, the most obvious effect is the similarities of entry order patterns among different firms. This clearly confirms the evidence that entry is not a smooth, homogeneous phenomenon, but it occurs in waves (Geroski, 1995). Finally, a robustness check, results are confirmed if we adopt different econometric models, logit regression for entry decision and simple Tobit regressions for entry order.

\section{Conclusions}

Up to date, literature presents two contrasting hypotheses to explain the latecomer attitude of de alio entrants in new markets: the rational $v s$ the inertial hypothesis. Using as background the theory of capabilities as real options (Kogut and Kulatilaka, 2001), this article presents one of the first empirical tests of these two hypotheses. Our empirical evidence based on SSI supports the view that de alio firms ignore some capabilities as real options because they suffer by inertia in the entry decision processes (Henderson and Clark, 1990). This implies that de alio entry performance is sub-optimal and it could be increased if managers adopt a more rational entry order strategy. Our evidence bridges also a gap between the management and the economic literature: our results are consistent with the industry life cycle evidence that shows how firms with a heterogeneous endowment of capabilities cluster their entry in similar period of time (Geroski, 1995).

Clearly, de alio entrants will not always fail in new markets. This article only suggests that the inertial attitude of de alio entrants could create difficulties in competing in new sectors, even if the de alio firms own all the resources necessary to build up a sustainable competitive advantage.

For example, SystemSoft, a medium size company specialized in operating system design, tried to exploit SSI rising demand since 1995 implementing a diversification strategy. In so doing, the firm signed several technological and marketing agreements with large ICT firms and in 1996 it bought Radish Communications System, with the aim of integrating Radish's competencies in data transmission technology. Nevertheless, Systemsoft never coped with its direct competitors like Network Associates and Symantec that entered in the sector some years before. After having realized a loss in 1997, Systemsoft tried to react with cost saving strategies but in 1999 the company filed for bankruptcy protection. In 1999 it sold off its assets to Rocket Software. 'We were late on many issues, and there were too many already consolidated specialized competitors. Hard to believe, there was a rising demand for security products and we were not able to find good customers', affirmed a product manager of Systemsoft (BusinessWire, 1999).

Our work presents some limitations and some caveats should be posed. One evident drawback is that we could not measure the post-entry performance of de alio entrants in SSI and so we cannot evaluate the importance of entry order in terms of performance. However, direct interviews conducted with some start-up managers confirm that early-comer start-ups have gained sound first mover advantages, especially in terms of downstream assets and product reputation. In these interviews, it surprisingly emerged that often start-ups does not perceive de alio entrants as direct competitors. Second, we are aware that entry process is analysed in a particular niche of software industry characterized by low entry and exit barriers and high rate of product innovation. The lack of any industry variance could limit the generality of our results, especially in terms of testing the link between capability real options and different levels of uncertainty. Further works should investigate these issues in other industries.

These limitations notwithstanding, the article discloses how inertial behaviours reduce the strategic value of firm capabilities. Even with perfect information, top managers should be aware that strategic mistakes in entry order could cause an under-exploitation of firm resources. This point relates directly to the concept of myopia in the management literature. The difference in the extent of firm performance could rely not only in the validity of the managers' strategic plans but also in the quality of the observation - especially of the links among firm resources, their potential applications in novel downstream product markets and entry order decisions (Dosi and Kogut, 1993). Therefore, when analytic observation is the real strategic option, myopia could be harmful. ${ }^{4}$

\section{Notes}

1 I thank the EMR Editor Bruce Kogut and two anonymous reviewers. The paper improves thanks also to the comments of Ashish Arora, Giovanni Dosi, Andrea Fosfuri, Steven Klepper, Alfonso Gambardella, Salvatore Torrisi and seminar parteci pants at Merit, IESE, Sant'Anna School of Advanced Studies, UC3M, WZB, Druid Summer Conference, EURAM Conference. Sponsoring from the Spanish Ministry of Science is gratefully acknowledged (SEJ2005 06655 and HI2005 0380). All errors are mine.

2 Entry order decision is usually not a meditated process for entrepreneurial start ups (the de novo entrants) that take their entry order decisions with scarce alternative options and low opportunity costs.

3 'Worldwide Internet Security Software Market to close in on 4.4 billion dollars in 1999', EDP Weekly's IT Monitor, 40(32), 1999: 18.

4 For the distinction between inference and analytic observation, see also Poe (1841). 


\section{References}

Amemiya, T., 1987, Advanced econometrics. Cambridge: Harvard University Press.

Aron, D. and E. Lazear, 1990, "The introduction of new products". American Economic Association: Papers and Proceedings, 80(2): 421-426.

Barr, P., 1998, "Adapting to unfamiliar environmental events: A look at the evolution of interpretation and its role in strategic change". Organization Studies, 9(6): 644-668.

Bhide, A., 2000, The origin and evolution of new businesses. New York: Oxford University Press.

Brock, W. and C. Hommes, 1997, "A rational route to randomness". Econometrica, 65(5): 1059-1095.

Burgelman, R. A., 1994, "Fading memories: A process theory of strategic business exit in dynamic environments". Administrative Science Quarterly, 39(1): 24-56.

BusinessWire, 1999, "Systemsoft to file for Protection under Chapter 11 of the US Bankruptcy Code". March: 28-31.

Carroll, G. R., L. S. Bigelow, M. D. L. Seidel and L. B. Tsai, 1996, "The fates of de-novo and de alio producers in the American automobile industry 1885-1981". Strategic Management Journal, 17(Summer Special Issue): 117-137.

Chesbrough, H., 2000, "Designing corporate ventures in the shadow of private venture capital". California Management Review, 42(3): 31-49.

Cho, D., D. Kim and D. Rhee, 1998, "Latecomer strategies: Evidence from semiconductor industry in Japan”. Organization Science, 9(4): 489-505.

Christensen, C., 1997, The innovator's dilemma. Boston: Harvard Business School Press.

Dong-Jae, K. and B. Kogut, 1996, "Technological platforms and diversification". Organization Science, 7(3): 283-301.

Dosi, G. and B. Kogut, 1993, "National specificities and the context of change: The coevolution of organization and technology". In B. Kogut (ed.) Country competitiveness: Technology and organizing of work. New York: Oxford University Press.

Dougherthy, D. and C. Hardy, 1996, "Sustained product innovation in large, mature organizations: Overcoming innovation to organization problems". Academy of Management Journal, 39(5): 1120-1153.

Dougherthy, D. and T. Heller, 1994, "The illegitimacy of successful product innovation in established firms". Organization Studies, 5(2): 200-218.

Dowell, G. and A. Swaminathan, 2000, "Racing and back-pedalling into the future: New product introduction and organizational mortality in the US bicycle industry". Organization Studies, 21(2): 405-431.

Economist (the), 2002, "Survey on digital security: Securing the cloud". 24th October, 43-44.

Fosfuri, A. and M. S. Giarratana, 2007, "Product strategies and survival in Schumpeterian environments: Evidence from the US Security Software Industry". Organization Studies, 28(6): 909-929.

Geroski, P., 1995, "What do we know about entry? International Journal of Industrial Organization, 13(4): 421-440.

Grever, H. and A. Taylor, 2000, "Innovations as catalysts for organizational change: Shifts in organizational cognition and search". Administrative Science Quarterly, 45(3): 45-80.

Hall, B. H., 1993, "The stock markets valuation of R\&D investment during the 1980s". American Economic Review, 83(2): 259-264.

Hagedoorn, J. and G. Duysters, 2002, "Learning in dynamic inter-firm networks: The efficacy of multiple contacts". Organization Studies, 23(4): 525-548.
Henderson, R. and K. Clark, 1990, "Architectural innovation: The reconfiguration of existing product technologies and the failure of established firms". Administrative Science Quarterly, 35(1): 9-30.

Henderson, R. and I. Cockburn, 1996, "Scale, scope, and spillovers: The determinants of research productivity in drug discovery". Rand Journal of Economics, 27(1): 32-59.

Jelinek, M., 1977, “Technology, organizations and contingency". Academy of Management Review, 2(1): 17-26.

Klepper, S., 2001, "Employee start-ups in high-tech industry". Industrial and Corporate Change, 10(3): 639-674.

Klepper, S. and K. Simons, 2000, "Dominants by birthright: Entry of prior radio producers and competitive ramifications in the US television receiver industry". Strategic Management Journal, 21: 997-1016.

Kogut, B. and N. Kulatilaka, 1994, "Operating flexibility, global manufacturing and the option value of a multinational network". Management Science, 40(1): 123-139.

Kogut, B. and N. Kulatilaka, 2001, "Capabilities as real options". Organization Science, 12(6): 744-758.

Levinthal, D. and J. March, 1993, "The myopia of learning". Strategic Management Journal, 14: 95-112.

Lieberman, M. B. and D. B. Montgomery, 1988, "1st mover advantages". Strategic Management Journal, 9: 41-58.

Mitchell, W., 1989, "Whether and when? Probability and timing of incumbents entry into emerging industrial subfields". Administrative Science Quarterly, 34(2): 208-230.

Mitchell, W., 1991, “Dual clocks: Entry order influences on incumbents' and newcomer market share and survival when specialized assets retain their value". Strategic Management Journal, 12(2): 85-100.

Mitchell, W. and K. Singh, 1996, "Survival of businesses using collaborative relationships to commercialize complex goods". Strategic Management Journal, 17(3): 169-195.

Nelson, R. R. and S. Winter, 1982, An evolutionary Theory of economic change. Cambridge: Harvard University Press.

Pavitt, K., M. Robson and J. Townsend, 1989, “Technological accumulation, diversification and organization in UK companies, 1945-1983". Management Science, 35(1): 81-99.

Poe, E. A., 1841, "The murders in the Rue Morgue". Graham's Magazine, 18: 106-107.

Schnaars, S., 1994, Managing imitation strategies. New York: Free Press.

Schoenecker, T. and A. Cooper, 1998, "The role of firm resource and organizational attributes in determining entry timing: A cross-industry study". Strategic Management Journal, 19(2): 1127-1143.

Silverman, B., 1999, "Technological resources and the direction of corporate diversification: Towards an integration of resource based view and transaction cost economy". Management Science, 45(8): 1109-1124.

Smith, C. and A. Cooper, 1988, "Established companies diversifying into young industries: A comparison of firms with different levels of performance". Strategic Management Journal, 9(2): 111-121.

Teece, D., R. Rumelt, G. Dosi and S. Winter, 1994, "Understanding corporate coherence: Theory and evidence". Journal of Economic Behavior and Organization, 23(2): 1-30.

Tushman, M. and P. Anderson, 1986, “Technological discontinuities and organizational environments". Administrative Science Quarterly, 31(2): 439465.

Winter, S., 1987, "Knowledge and competence as strategic assets". in D. Teece (ed.) The competitive challenge: Strategies for industrial innovation and renewal. New York: Harper, pp: 159-184. 